\title{
THE IMPORTANCE OF DEVELOPMENT FUNDS AT COMPANIES RECEIVING STATE-AID GRANTS ${ }^{1}$
}

György Vas

In order to make use of non-repayable state grants, firms need to possess internal funds, which we can refer to as internal funds for development. The value of these is equal to the funds accumulated over previous years; that is, the relatively broadly defined accumulated profit. The benefit of development projects implemented with grants is that they increase social value added; but without the appropriate incentives, firms have a tendency to simply boost their individual profitability. We can identify this as a moral hazard of the grants. This study examines how the extent of this moral hazard can be deduced based on quality parameters, and it explores the relationship between the size of a development project, the available internal funds and the paid-out grants. It analyses in detail the consequences of overfunding and underfunding, which can be identified in terms of their impacts on the social value added.

JEL codes: $\mathrm{O} 11, \mathrm{O} 12$

Keywords: moral hazard, development policy, financing

\section{INTRODUCTION}

The continuous development of companies' operations could be one of the most substantial sources of growth in revenue and profitability; and non-repayable government grants are available for this. One prerequisite for making use of the grants is that the applicant must possess sufficient internal funds. Development funds are one of the most important elements of the firms' operation, as they facilitate the implementation of future development projects and ensure the growth of firms. Internal Funds for Development (IFD) are liquid assets deriving from the firms' profitable operation, and from depreciation not spent on investment or replacement, the value of which is significantly influenced by the financial settlement of EU non-repayable grants.

1 The author is a researcher at the Small Business Development Centre of Corvinus University, Budapest. 
Unlike funds obtained from financial institutions, state grants, which are intended to boost competitiveness and employment while stimulating investment and innovation, do not have to be repaid provided that the purpose of the aid has been achieved. Banerjee-Duflo (2004) and Miller-Rojas (2004) refer to funds obtained from financial institutions as one of the most significant factors in the growth of an enterprise, and in this regard Beck (2007) draw attention to the limited nature of funds accessible to SMEs. It is precisely with a view to softening credit constraints that assisted lending programmes (Griffith-Jones et al., 2011) and nonrepayable grants $(E C, 2015)$ are used. These methods of state aid are similar in that they both make procuring factors of production cheaper, and in this way exert their economic-stimulus effect. The companies, therefore, do not repay the money in cash, but instead generate social value added by achieving economic development objectives. It is important to examine this process in more depth, because owing to the moral hazard we can observe that, in the absence of appropriate incentives, companies may give preference to maximising their own profitability rather than increasing the social value added.

Non-repayable state aid grants create an additional opportunity to obtain funds for the implementation of developments, in excess of what can be achieved with internal funds, and to improve competitiveness through a reduction in the acquisition cost of production tools. The operating mechanism of financing by commercial banks is as follows: The financial intermediation system offers financial resources and requests collateral to secure them, the company repays the principal and pays the interest on it. During the provision of direct state aid grants, firms also receive funds for a defined purpose, but do not pay interest on it; and if the development objective is fulfilled, it does not even have to be paid back. In this event, the state receives social value added in return for the financial aid. In the case of bank financing, the moral hazard is that of a company taking out a loan in the knowledge that it will be unable to repay it. When it comes to state aid, the received funds do not have to be repaid, so the definition of the moral hazard also changes accordingly. In the case of state aid, the basic scenario of the moral hazard is where the entrepreneur knows that he or she will not generate social value added, but nevertheless uses or applies for the non-repayable grant.

If state grants are paid out, firms can achieve higher accumulation of equity because the paid-out amounts of aid are stated as profit-increasing items during the amortisation period. The firms' liquid assets, similarly to projects implemented with non-repayable grants, increase by the value of the given year's profit and depreciation during the maintenance period; but firms that have received grants can recognise the part of the previously paid aid apportioned to the given year as a profit-increasing item. This means that the profit and retained earnings of the subsidised firms, and through this their equity, grows by more. It is through this 
mechanism that state aid grants lead accelerated capital accumulation at firms receiving state aid.

It is in the state's interest to support projects that benefit society, because this is how firms repay the funds transferred to them. It is no simple task to select the cases in which the social value added matches the given economic-policy objective. Owing to the asymmetric distribution of information, the businessperson knows about several quality parameters relating to his or her own project that he or she does not share, or only partially shares, with the bank. This is a passive behaviour pattern, resulting in a choice: the entrepreneur plans to use a service that will increase his individual profitability, but for the lender it might result in a loss. Means of reducing moral hazard could be obtaining supplementary information or requesting a certain amount of internal funds. This makes it possible to achieve a situation in which projects that really do have better quality parameters, and thus a better chance of success, receive financing or state aid. This is why I am examining more closely the Internal Funds for Development, by which I mean the amount of available liquid assets previously generated by the firms, which can be used for implementing further development projects.

\section{MORAL HAZARD OF STATE AID}

No empirical studies can be found that discuss moral hazard of EU state aid grants. This may be because it is difficult to analyse an incentive-related problem based on macroeconomic data. For this, we need to set up an analytical framework that specifically examines moral hazard in relation to state grants. No such theoretical model is available, however, and several reasons for this can be identified. Firstly, we can define several forms of state intervention, including but not limited to the bail-out of a corporation or sector, the provision of interest-free funds of development banks, or the granting of direct non-repayable aid. In domestic practice, the intermediation system created for the transfer of EU funds to SMEs has a high weight within the system of development policy tools. This is also underpinned by the fact that strengthening the SME sector is a key economic development objective, which in the 2007-2013 period received HUF 811.5 billion paid out under the Economic Development Operative Programme (GOP), to be followed in the 2014-2020 cycle - according to plans - by some HUF 2,733 billion in direct aid under the Economic Development and Innovation Operative Programme (GINOP). ${ }^{2}$

2 http://gazdasagfejlesztes.gov.hu/sites/default/files/gazdagsagfejlesztes_2015_kiadvany.pdf 
International literature is divided in its views of state intervention. Tirole (2009), following on from Holmstorm-Tirole (1997), continues to see the state's role in corporate lending as being limited to bail-out. The analytical background of the Holmstrom-Tirole model could serve as an excellent basis for analysing the mechanism of effect of direct state grants; but it must be stressed that it views the state's role as something completely different. It distinguishes between fiscal and monetary bail-out, which it defines in different ways. This is the only form in which the model defines state aid; that is, as a type of state intervention, and it does not regard the state aid examined in my research as an economic stimulus tool. In the Hungarian literature, the correlation between moral hazards and grants is investigated by Berlinger et al. (2015; 2016). In his detailed analysis of the economic stimulus measures of the 2008 economic crisis, Vives (2010) also regards the money pumped into the financial intermediation sector as state aid. The author gives an excellent overview of the complete rearrangement of the European banking market, in which the financial institutions restructured, or sold and reorganised their operations with the aim of reducing their moral hazard.

State intervention was interpreted as taking the form of regulation, which can be defined as a trade-off between competition and stability. Berger-Udell (2006) proposes a general framework for the examination of access to credit by SMEs. They highlight that access to external finance by SMEs is both an important theoretical economic issue and a key problem for policy-makers. Kállay (2014) examines the spill-over effect of state grants provided to SMEs, which he pinpoints as an improvement in income-generating capacity and competitiveness. He proposes that, in addition to the abundance of funds, the economic and regulatory environment in which the SMEs eventually receive the grants also needs to be examined. A hard-to-predict economic environment, and competing aid programmes, give rise to problems like crowding out. It's important to find the parallels between state grants and bank financing; and use them as a lens through which to read research papers which, at first glance, appear to examine entirely different issues. Kállay's study contains an implicit examination of the framework, relating to the mechanism of effect of state grants, which Berger-Udell (2006) describes explicitly in relation to SME lending problems. They describe in detail how the access of SMEs to credit is influenced by the structure of the banking system and by government interventions, through their impact on the lending methodology. 


\section{THE USE OF INTERNAL FUNDS IN DEVELOPMENT PROJECTS}

In what follows, we examine the availability of internal funds in the development projects in relation to the grants awarded to the SME sector during the 2007-2013 EU planning cycle. Prior to making use of the grants, the firm concerned had differing extents of internal funds. Certain firms would have been capable of implementing the entire development project without any external help whatsoever. The question is whether it could be regarded as desirable from an economic development perspective to support firms which would anyway be capable of implementing the development project without the grant.

The table below shows the ratios of the company's deposits as a percentage of the value of planned investment. The first five columns each cover a range of ten percent; companies possessing less than one tenth of the expenses of the development to be implemented represented 28 percent of all the firms that received aid. Adding together the items in the next four columns shows that 64 percent of the firms had less than half, while around a fifth of the subsidised firms $(15+$ 6 percent) would have been capable of implementing a larger investment project than originally planned while applying for the non-repayable funds. It is also thought-provoking that almost half of the firms did not even possess internal funds amounting to 20-30 percent of the total investment cost.

Table 1

Savings of firms receiving grants, as a percentage of development project cost

\begin{tabular}{|c|c|c|c|c|c|c|c|c|}
\hline & $\begin{array}{c}0- \\
10 \%\end{array}$ & $\begin{array}{l}10- \\
20 \%\end{array}$ & $\begin{array}{l}20- \\
30 \%\end{array}$ & $\begin{array}{l}30- \\
40 \%\end{array}$ & $\begin{array}{l}40- \\
50 \%\end{array}$ & $\begin{array}{c}50- \\
100 \%\end{array}$ & $\begin{array}{l}100- \\
150 \%\end{array}$ & $150 \%+$ \\
\hline $\begin{array}{l}\text { As a proportion } \\
\text { of all firms }\end{array}$ & $28 \%$ & $14 \%$ & $9 \%$ & $7 \%$ & $6 \%$ & $15 \%$ & $6 \%$ & $15 \%$ \\
\hline $\begin{array}{l}\text { Cumulative } \\
\text { value }\end{array}$ & $28 \%$ & $42 \%$ & $51 \%$ & $58 \%$ & $64 \%$ & $79 \%$ & $85 \%$ & $100 \%$ \\
\hline
\end{tabular}

Source: own research, palyazat.gov.hu

SMEs grow if they have sufficient internal funds available for development projects. The market value of companies can only be increased by reliably and predictably high cash-generating capacity. All ad-hoc or one-off interventions can have a positive impact on the firms' operation and market value. At the time of payment of the grants, however, the research question concerns the extent of the positive impact that the one-off intervention could have on the firms' operation. Increasing sales revenues is not an aim, but a tool of the development projects; 
the primary objective is improving profitable operation, which we can identify as growth in the value of equity from the profit accumulated over the years.

When an enterprise implements a development project, production tools are stated in the books at their true acquisition cost. In the case of development projects, we would like to show the social value added; but this remains hidden, and we can only monitor the impact on economic indicators relating to the whole enterprise. As a result of the non-repayable grant, firms' sales revenue increases because during the maintenance period the amount of the grant, which was formerly stated as an accrual, can be released and recognised as other revenue. Due to this, in comparison with a similar sized competitor implementing a similarsized project that has not received a non-repayable grant, the profit will also increase; and this in turn will raise the value of equity through the increase in retained earnings. The social value added takes the form of growth in the equity of the companies that have received a grant, which materialises in the growth of current assets; in other words, it appears as savings, bank deposits, thereby generating internal funds for the next development project. The grant, therefore, is a substantial contribution to the firms' next development project or investment, for which the company will be able to assemble the internal funds more quickly due to the increased profitability.

The success of the development policy has to be separated from the success of the firm themselves. To be more precise, I propose that the growth in a firm's general profitability should not be regarded as the main characteristic. Let's take a typical, ideal enterprise that has received a non-repayable grant and/or discounted credit from a development banking system, and/or any credit product from the commercial banking sector. Here there are four possible outcomes, depending on whether firms made use of one or both of the loans in addition to the grant. Specifically, whether it

- received a grant

- received a grant and development credit

- received a grant and a commercial bank loan

- received a grant, development credit and a commercial bank loan.

If we also examine the possibilities in terms of the internal funds available for implementation of the development project, then in one scenario the internal funds would be sufficient, but a grant and discounted and/or commercial bank credit are used nevertheless; while in the other, the internal funds would not be sufficient, which is why the discounted and/or commercial bank credit are used. This makes 10 basic scenarios, which are then supplemented with the additional variable of whether a business partner is involved in the development, thus increas- 
ing the number of possible outcomes to 20. The simplest scenario is that internal funds would be sufficient for implementation of the project, but firms accept a grant for its implementation. The most complex scenario is where firms' internal funds are not sufficient for implementation of the project, and therefore it makes use of a grant, interest-subsidised and market-rate credit, as well as the collaboration of a business partner.

The projects implemented in this way can have a negative or positive impact on the cash-generating capacity of the firms as a whole. As a consequence of this, the whole enterprise may go from being profitable to being more profitable or less profitable, or from loss-making to being profitable, or from loss-making to being less loss-making or more loss-making. These five possible outcomes increase the number of basic scenarios defined earlier to one hundred. This means that, with respect to grants, there is a total of 100 different possible basic scenarios that can be compared with each other to a limited extent. If we examine the impact on social value added of the use of a grant by a formerly profitable enterprise that became less profitable after using the grant, and which possessed sufficient internal funds for implementation of the development project but still made use of a commercial bank loan, then this should be compared with an enterprise implementing a development project of a similar volume and size that did not receive a grant, but drew down commercial bank funds despite possessing the full amount of liquid assets necessary for the implementation. If there is any divergence in the parameters; that is, if we do not compare companies of the same size, then the result will be distorted. However, we cannot forecast the direction of this, and there are no available experiential facts that could help us do this.

The costs and risks of implementing the development project are known to firms at the time of planning the project, as are the revenue plans and the costs of operation; and based on these, it is possible to compile the profit plan for the return on the project, and the cash-flow statement, which together can be used to determine the return on the development project. The grant, however, is applied for by an operational business, and accordingly not only does the project have to yield a return, but the whole enterprise has to profit from it, since the logic of the aid system is based not on projects, but on subsidised firms.

Firms have to define the cost-cutting benefit of the development project, but at the same time it needs to identify the additional costs arising due to the requirements of the funding application system, as well as the quantifiable costs of the increase in risk. The slowing in the rate of revenue growth due to the requirements of the funding application system also has to be determined, although it is also possible to assume that this is zero. If all the modifying factors have successfully been identified, then it becomes possible to compare the costs and revenues of the project implemented under the aid contract with those of the 
original development project; and the difference between these also reflects the bridging costs incurred due to the ex-post financing. In this way, the return on the two projects becomes comparable, and thus the difference can also be calculated. From this, we can deduce the perceived costs of the assets transferred free of charge.

In relation to direct state aid, the moral hazard can be defined as follows: An enterprise applies for direct state aid although it does not contribute to an increase in social value added. The formal modelling of the moral hazard of direct state aid grants is addressed by mainstream international research. The analytical model set up by Holmstrom-Tirole (1997), regarded as a seminal work for research into both state aid grands and SME financing, does not examine direct state aid, but investigates the role of the state as a potential source of financial bail-out. Berlinger et al. (2016) extend the study to encompass direct state aid and assisted loans, but use basic assumptions based on which the moral hazard of state aid cannot be investigated in more depth. Owing to the assumption of risk-neutral actors, a constant size increase and positive external conditions, the conclusions cannot be applied to the problem investigated in my research.

\section{DEFINING INTERNAL FUNDS FOR DEVELOPMENT}

For a high number of firms, we need to determine the indicator that provides the value of internal funds necessary for implementing the development projects. At the point of making the investment decision, firms need to be aware of their Internal Funds for Development at that moment in time. By this we mean existing liquid assets, or those that can be mobilised within a relatively short time, over which firms have disposal. In practice, this means cash, bank deposits or money invested in securities, and there may also be investment assets which can be sold in the given business year, such as real estate, artworks, etc. Here, it is important to note that if there is a substantial divergence between the calculated Internal Funds for Development and the available liquid assets, then the cause of this divergence might be some operational issue.

For the purpose of investigating the accounting settlement of the grants and their impacts on economic development, we can review the publicly available economic data that firms disclose annually as a part of their mandatory reporting. When evaluating the business management of a company, profitability is one of the most important factors. A direct consequence of the accounting settlement of the grants is that the companies receiving grants will grow relative to those that have not received them. It is also important, however, to examine how firms would manage their resources without the profit-boosting effect of the state aid 
grant, as this shows how the firms' income-generating capacity would have developed ceteris paribus. It is advisable to perform this analysis on a group of firms of a similar size, which are active in the same sector and region.

Submission of the funding application took place during the calendar year, so the values may have changed mid-year as a consequence of certain economic events, because

- payments may already have been made in connection with the funding application

- there may have been significant movement in the volume of liquid assets, due to the change in working capital

- dividends may have been paid out

- any payment may have been made in connection with another investment that is the subject of a funding application

- certain financing decisions may have altered the volume of liquid assets

- personnel-related withdrawals of cash may have occurred.

In what follows, I will examine the potential distorting effect of the individual modifying factors, with a view to selecting the most accurate indicator of internal funds for development. While firms are aware of the extent of available internal funds at the moment of the investment decision, clearly defining this in retrospect can run into difficulties. The possibilities are presented below.

\section{1) Deposits in the year of submitting the application}

This indicator shows the cumulative cash flow, in the event that firms retain all previously accumulated profit. Domestic SMEs have low capitalisation, so if the accumulated liquid assets are serving as a form of capital replacement in the course of the firm's operation, then the value of deposits may be substantially lower than the profit accumulated in previous years.

2) Deposits in the year prior to submitting the application

With this, we can estimate the value of available internal funds more accurately if we assume that payments related to implementation of the development project were made in the year of submitting the application. In this case, the value of deposits at the end of the previous year better expresses the firm's liquidity position, because this is the amount that may have been available when the decision to apply for funding was made. 


\section{3) Retained earnings in the year of submitting the application}

Expenses may be incurred in the interest of the subsidised project after submission of the application; but typically, those are due after the decision has been made to grant the aid. Consequently, the profit for the given year, and its recognition, could still be important when determining the size of the development project.

\section{4) Retained earnings in the year prior to submitting the application}

If we assume that firms make the decision to launch the development project some time in advance, then it could be reasonable to look at the value of retained earnings at an earlier point in time.

We have to decide what type of balance sheet item could be most suitable for estimating the accumulation of an firms' funds available for development purposes: an asset, namely the firms' more broadly defined liquid assets, or a liability, i.e. retained earnings. For the investigation, it is still necessary to consider whether we are examining these items in the year of submitting the application or in the previous year. We could also propose a composite indicator, which shows what share of the firms' retained earnings is available in the form of liquid assets. This could be the ratios of the firms' deposits, retained earnings and equity to each other. However, this indicator would only provide information about the firms' capital structure, and it offers no substance for an investigation of the economic-stimulus effect of the grants. Finally we can conclude that, for the empirical studies, observing the economic data of the companies, the retained earnings in the year of submitting the application may be the most precise definition of the Internal Funds for Development.

The table below shows the value of retained earnings and volume of deposits measured in the year of submitting the application at companies submitting a funding application in each individual year. The last column shows the ratio of retained earnings to deposits. The year 2007 , the first annual period in the sevenyear planning cycle, is not shown in the table because only a few hundred firms submitted grant applications in that year. 
Table 2

Selected data of firms submitting grant applications

\begin{tabular}{cccc}
\hline & $\begin{array}{c}\text { Retained earnings / } \\
\text { Project size }\end{array}$ & $\begin{array}{c}\text { Bank Deposits / } \\
\text { Project size }\end{array}$ & $\begin{array}{c}\text { Retained earnings / } \\
\text { Bank Deposits }\end{array}$ \\
\hline 2008 & $49.249 \%$ & $25.921 \%$ & 1.9 \\
2009 & $86.350 \%$ & $46.444 \%$ & 1.9 \\
2010 & $76.711 \%$ & $36.941 \%$ & 2.1 \\
2011 & $121.662 \%$ & $75.049 \%$ & 1.6 \\
2012 & $56.098 \%$ & $26.034 \%$ & 2.2 \\
2013 & $123.652 \%$ & $57.816 \%$ & 2.1 \\
2014 & $134.968 \%$ & $41.060 \%$ & 3.3 \\
2015 & $81.510 \%$ & $55.186 \%$ & 1.5 \\
\hline
\end{tabular}

Source: own research, MNB, KSH

It is clear that in the first three years, the retained earnings of firms that were awarded grants are regularly twice the value of their deposits, and this is in line with the eight-year average, which shows a figure of 2.1. The years 2011 and 2015 diverged downwards, while in 2014 the difference more than tripled. In addition to 2011 and 2015, the year 2014 was also characterised by retained earnings that exceeded the project size on average. While there was relative stability over the examined eight years in terms of the ratio of retained earnings to deposits, in comparison to the project size the volume of deposits moves within a range of 25-75 percent without any real trend, and retained earnings were between 49 and 135 percent. The explanation is that, in each year, different assisted and commercial-bank financing was available to supplement the grants.

And this brings us to the comparability problem: Based on the economic indicators, we observe that the internal funds identified as Internal Funds for Development show considerable trendless movement, which signifies the attitude of economic actors to the use of non-repayable grants. In the case of non-repayable grants we have defined moral hazard as being the risk of firms utilising the aid without creating any social value added; but the empirical observation of this only becomes possible in the years following the grant payments, when firms prepare their financial statements for the years following payment of the grants, and make them available to the Tax Authority and the Controlling Authority manag- 
ing the grants. From this, it is possible to deduce the extent to which firms were able to improve their own economic performance with the non-repayable funds, and thus create social value added.

\section{SUMMARY}

Non-repayable state grants are an ex-post funding instrument. This means that firms have to possess sufficient funds for full implementation of the funded project, which may consist of internal funds, institutional funding sources, bridging funds from a business partner, or other tendered funds. It is up to firms to implement the project, and if it can prove that this has taken place in accordance with the terms of funding, then the funds that have been applied for are paid out.

It is important to clarify what really takes place between the state and the subsidised enterprise when a grant is awarded. One question is whether (1) a reallocation of funds takes place; in other words, do firms simply replace their external funding requirements with the cheapest available funds, which we refer to as crowding out. If (2) a reallocation of income takes place, then besides achieving higher profitability, firms receiving the state aid could also see an increase in capital accumulation. This can boost the competitiveness of the assisted firm, thanks to the improvement in their capital structure. If (3) a transfer of assets takes place, then the machines, equipment or rights come under the firm's ownership free of charge, thereby increasing the value of the firm.

The shareholder value of firms can grow in all three scenarios, indirectly due to the higher income-generation and better profitability in the first two cases, and directly as a consequence of the lower acquisition cost of the production tools in the third scenario. The grant constitutes a one-off impact in the life of an enterprise, so it is important to investigate what impact it may have on firms' operation during the maintenance period and generally in the years that follow. This data will become available in the years ahead. 


\section{REFERENCES}

Abbring, J. H. - Chiappori, P. - Pinquet, J. (2003): Moral hazard and dynamic insurance data. Journal of the European Economic Association 1(4).

Agoraki, M. E. - Manthos, D. (2011): Regulations, competition and bank risk-taking in transition countries. Journal of Financial Stability $7(1)$.

AKerLof, G. (1970): The Market for "Lemons": Quality Uncertainty and the Market Mechanism. The Quarterly Journal of Economics, 84(3), 488-500.

Arnold, L. G. - Riley, J. G. (2009): On the possibility of credit rationing in the Stiglitz-Weiss Model. The American Economic Review, 99(5), 2012-2021.

BABBIE, E. R. (2013): The practice of social research. Wadsworth, Cengage Learning.

Banerjee, A. - Duflo, E. (2004): Do Firms Want to Borrow More. Testing Credit Constraints Using a Directed Lending Program. Massachusetts: MIT.

BECK, T. (2007): Financing constraints of SMEs in developing countries: Evidence, determinants and solutions. KDI 36th Anniversary International Conference.

Beck, T. - Demirgüç-Kunt, A. - Maksimovic, V. (2004): Bank competition and access to finance: International evidence. Journal of Money, Credit and Banking, 36(3), 627-648.

Bellucci, A. - Borisov, A. - Zazzaro, A. (2016): Bank Organization and Loan Contracting in Small Business Financing. IAW Discussion Papers No. 122, Tübingen: Institut für Angewandte Wirtschaftsforschung eV.

BERGER, A. N. (2004): Bank concentration and competition: An evolution in the making. Journal of Money, Credit and Banking, 36(3).

BERGER, A. N. (2006): A more complete conceptual framework for SME finance. Journal of Banking \& Finance, 30(11), 2945-2966.

Berger, A. N. - Udell, G. (1995): Relationship lending and lines of credit in small firm finance. Journal of Business, 68(3), 351-381.

Berger, A. N. - Udell, G. (2002): Small business credit availability and relationship lending: The importance of bank organisational structure. The Economic Journal, 112(477).

Berlinger, E. J. (2015): The Impact of State Aid on Project Finance with Moral Hazard and Postive Externals [Az állami támogatás hatása a projektfinanszírozásra erkölcsi kockázat és pozitív externáliák mellett]. Közgazdasági Szemle, 62(2), 139-171.

BerLinger, E. - Lovas, A. - JuhÁsz, P. (2016): State subsidy and moral hazard in corporate financing. Central European Journal of Operations Research, 25(4), 743-770.

Bodnár, V. - DANKó, D. - Kiss, N. - VAS, G. (2007): Changes in the management control toolkit of hungarian organizations (1996-2006). Working paper, Budapest: BCE.

Bourgeois, J. -DAwAR, K. - Evenett, S. (2007): A comparative analysis of selected provisions in free trade agreements. DG Trade, Brussels: European Commission.

Brealey, R. A. (2012): Principles of corporate finance. . Tata McGraw-Hill Education.

BURRelL, G - Morgan, G. (1979): Sociological paradigms and organisational analysis, 248, London: Heinemann.

Campello, M. - Graham, J. - Harvey, C. (2010): The real effects of financial constraints: Evidence from a financial crisis. Journal of Financial Economics, 97(3).

Carbó-Valverde, S. - Rodríguez-Fernandez, F. - Udell, G. (2009): Bank market power and SME financing constraints. Review of Finance, 13(2).

Cardon, J. H. - Hendel, I. (2001): Asymmetric information in health insurance: evidence from the National Medical Expenditure Survey. RAND Journal of Economics 32(3), 408-427. 
CoAse, R. H. (1936): The nature of the firm. Economica, 4(16).

Collewaert, V. (2012): Angel investors' and entrepreneurs' intentions to exit their ventures: A conflict perspective. Entrepreneurship Theory and Practice, 36(4), 753-779.

Conning, J. (1996): Group lending, moral hazard, and the creation of social collateral. University of Maryland at College Park: Center for Institutional Reform and the Informal Sector.

DARvas, Z. (2014): Can Europe recover without credit? Society and Economy, 36(2).

Diamond, D. W. - Rajan, R. G. (2000): A theory of bank capital. The Journal of Finance, 55(6).

Diaz-Serrano, L. - Sackey, F. (2015): Is Rationing in the Microfinance Sector Determined by the Microfinance Type? Evidence from Ghana. IZA Discussion Papers, No. 8999.

Dionne, G. (2005): The role of memory in long-term contracting with moral hazard: Empirical evidence in automobile insurance. Available at SSRN 764705.

Drótos, G. - GAst, K. - Móricz, P. - VAs, G. (2006): The development of the information management and competitiveness [Az információmenedzsment fejlettsége és a versenyképesség]. BCE: Versenyképesség kutatások mühelytanulmány-sorozat, 28.

Eisenhardt, K. M. (1989): Agency theory: An assessment and review. Academy of Management Review, 14(1).

El Ouafy, S. - Chakir, A. (2015): Financing micro businesses in Morocco: Case studies. European Journal of Business and Social Sciences, 4(2).

EC (é. n.): Article 88 of the EC Treaty (ex Article 93). Retrieved from ec.europa.eu, http://ec.europa. eu/competition/legislation/treaties/ec/art88_en.html.

EC (2015): State Aid Scoreboard 2015, http://ec.europa.eu/competition/state_aid/scoreboard/index_ en.html.

Farhi, E. - Tirole, J. (2009): Collective Moral Hazard. Maturity Mismatch and Systemic. NBER Working Paper, 15138.

Ford, G. - Koutsky, T. - SpIWAK, L. (2007): A valley of death in the innovation sequence: an economic investigation. Available at SSRN 1093006.

Greenwald, B. C. - Stiglitz, E. J. - Weiss, A. (1984): Informational imperfections in the capital market and macro-economic fluctuations. NBER Working Papers, 1335.

Griffith-Jones, S. - Tyson, J. - Calice, P. (2011): The European Investment Bank and SMEs: Key Lessons for Latin America and the Caribbean. ECLAC, Serie Financiamiento del Desarrollo, 236.

Hellmann, T. F. - Murdock, K. C. - Stiglitz, J. E. (200o): Liberalization, moral hazard in banking, and prudential regulation: Are capital requirements enough?. American Economic Review, 90(1), 147-165.

Holmstrom, B. (1979): Moral hazard and observability. The Bell Journal of Economics, 10(1), 74-91.

Holmstrom, B. - Tirole, J. (1997): Financial intermediation, loanable funds, and the real sector. The Quarterly Journal of Economics, 112(3).

Hoshi, T. - Kashyap, A. - Scharfstein, D. (1991): Corporate structure, liquidity, and investment: Evidence from Japanese industrial groups. The Quarterly Journal of Economics, 106(1), 33-60.

IvashinA, V. - (2010): Bank lending during the financial crisis of 2008. Journal of Financial Economics, $97(3), 319-338$.

Jaffee, D. - Stiglitz, J. (1990): Credit rationing. Chapter 16 in Handbook of Monetary Economics, $2,837-888$.

KÁllAY, L. (2014): State grants and economic performance - Aid overdosing in hungarian economic development? [Állami támogatások és gazdasági teljesítmény - Támogatás-túladagolás a magyar gazdaságfejlesztésben?] Közgazdasági Szemle, 61(3), 279-298. 
KÁLlAY, L. - VAS, G. (2017): The impact of state aid on social welfare (forthcoming).

KAPLAN, B. - MAXWELL, J. A. (2005): Qualitative research methods for evaluating computer information systems. Evaluating the organizational impact of healthcare information systems. New York: Springer.

Keuschnigg, C. (2001): Public policy for venture capital. International Tax and Public Finance, 8(4), 557-572.

Kieser, A. - Ebers, M. (2006): Organisationstheorien. Stuttgart: W. Kohlhammer Verlag.

Lovas, A. (2012): Innovation support and moral hazard - The impact of State aid [Innováció-finanszírozás erkölcsi kockázat mellett - Az állami beavatkozás hatása]. Corvinus University of Budapest [BCE], 05.11.2012.

Mannonen, P. (2002): The Strategic Response of Banks to an Exogenous Positive Information Shock in the Credit Markets. ETLA Discussion Papers, 830 .

Maxwell, J. (2005): Qualitative Research Design: An Interactive Approach. Thousand Oaks, CA: Sage.

MAXWELL, J. (2012): A realist approach for qualitative research. CA: Sage.

MilleR, M. - RojAs, D. (2004): Improving access to credit for smes: an empirical analysis of the viability of pooled data sme credit scoring models in Brazil, Colombia \& Mexico. World Bank Working Paper.

Miyazaki, H. - Aman, H. (2015): Effects of Regional Bank Merger on Small Business Borrowing: Evidence from Japan. International Journal of Economics and Finance, $7(11)$.

MNB (2017): A Növekedési Hitelprogram eredményei. https://www.mnb.hu/letoltes/a-novekedesihitelprogram-eredmenyei-honlapra-20170613.pdf.

OECD (2005): OECD SME and Entrepreneurship Outlook, 2005. OECD Publishing,

Oricchio, G. (2017): European Funding of SMEs through Securitization: An Introduction. In:

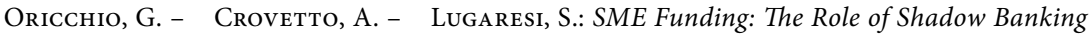
and Alternative Funding Options, Chapter 3. UK: Palgrave Macmillan.

Osawa, Y. - Miyazaki, K. (2006): An empirical analysis of the valley of death: Large scale R\&D project performance in a Japanese diversified company. Asian Journal of Technology Innovation, 14(2).

Petersen, M. - Rajan, R. (1995): The effect of credit market competition on lending relationships. The Quarterly Journal of Economics 110, 404-473.

RAMSKOGLER, P. (2007): Uncertainty, market power and credit rationing. Vienna University of Economics \& B. A., Department of Economics Working Paper Series, Working Paper 105.

Repullo, R. - SuAREZ, J. (2000): Entrepreneurial moral hazard and bank monitoring: a model of the credit channel. European Economic Review, 44(10).

Repullo, R. - Suarez, J. (2013): The procyclical effects of bank capital regulation. Review of Financial Studies 26(2).

Richaudeau, D. (1999): Automobile insurance contracts and risk of accident: An empirical test using French individual data. The Geneva Papers on Risk and Insurance Theory, 24(1).

Ross, S. A. (1973): The economic theory of agency: The principal's problem. The American Economic Review, 63(2).

SHEN, Y. (2009): Bank size and small-and medium-sized enterprise (SME) lending: Evidence from China. World Development, $37(4)$.

SHENG, J. (2014): The Real Effects of Government Intervention: Firm-Level Evidence from TARP. 2014 North American Summer Meeting of the Econometric Society, 2014 Northern Finance Association Conference. 
Simonovits, A. (2006): Optimal design of pension rule with flexible retirement: The two-type case. Journal of Economics, 89(3).

Simonovits, A. - Hillinger, C. (1993): Cyclical Growth in Market and Planned Economies. Journal of Economics, $57(3)$.

Stiglitz, J. E. - Weiss, A. (1981): Credit rationing in markets with imperfect information. The American Economic Review, 71(3), 393-410.

Stiglitz, J. E. - Weiss, A. (1987): Credit rationing: reply. The American Economic Review, 77(1).

TASH, F. H. (2016): Motives for Entrepreneurial Saving: Evidence from Sweden.

Tirole, J. (1988): The Theory of Industrial Organization. Cambridge (MA), London (UK): MIT Press.

VIves, X. (2010): Competition and stability in banking. The Role of Regulation and Competition Policy. New Jersey: Princeton University Press.

Ylhäinen, I. (2010): Persistence of government funding in small business finance. The Research Institute of the Finnish Economy, Discussion Papers 1232. 